\title{
Adverse childhood experiences in women with externalisation and internalisation disorders
}

\author{
Krzysztof Gasior (D) 1,2 A,B,C,D,E,F, fan Chodkiewicz (D) ${ }^{3 \cdot A, C, D, E, F}$ \\ 1: Institute of Pedagogy and Psychology, Jan Kochanowski University, Kielce, Poland \\ 2: Świętokrzyskie Centre of Prophylaxis and Education, Kielce, Poland \\ 3: Institute of Psychology, University of Lodz, Lodz, Poland
}

BACKGROUND

The aim of the study was to determine the connections between adverse childhood experiences and complex posttraumatic disorders and attachment types in women with externalisation (addictions, crime) and internalisation disorders (anxiety disorders and mixed anxiety-depressive disorders).

\section{PARTICIPANTS AND PROCEDURE}

The methods used in the study were as follows: Adverse Childhood Experiences - International Questionnaire (ACE-IQ), Family of Origin Dysfunction Scale (FODS) by Gąsior, Brier's Trauma Symptom Inventory-2 (TSI-2) and Adult Attachment Scale (AAS) by Collins and Read. The studied group comprised women $(N=159)$ with externalisation issues (addicted, $n=80$, including the addicted and incarcerated $n=23$ ) and with internalisation issues $(n=79)$. The overall results of the clinical groups were compared with the control group of women without adaptation issues $(N=129)$.
RESULTS

The examined groups of women with internalisation and externalisation disorders differ both in terms of intensity and the scope of adverse childhood experiences, as well as in complex post-traumatic stress and attachment extent. The results obtained and the conclusions drawn from the research indicate that it is necessary to include a detailed diagnosis of adverse childhood experiences and traumas in the therapy and social rehabilitation of women with internalisation and externalisation disorders.

\section{CONCLUSIONS}

Development trajectories of externalisation and internalisation issues in women in view of their adverse childhood experiences require further studies.

\section{KEY WORDS}

adverse childhood experiences; complex post-traumatic stress; externalisation and internalisation disorders

CORRESPONDING AUTHOR - Prof. Jan Chodkiewicz, Institute of Psychology, University of Lodz, 10/12 Smugowa Str., 91-433 Lodz, Poland, e-mail: jan.chodkiewicz@uni.lodz.pl

Authors' contribution - A: Study design · B: Data collection · C: Statistical analysis · D: Data interpretation ·

E: Manuscript preparation · F: Literature search · G: Funds collection

TO CITE THIS ARTICLE - Gąsior, K., \& Chodkiewicz J. (2020). Adverse childhood experiences in women with externalisation

and internalisation disorders. Current Issues in Personality Psychology, 8(2), 119-130.

RECEIVED 10.10.2019 • REVIEWED 25.04.2020 • ACCEPTED 11.05.2020 • PUBLISHED 08.06.2020 


\section{BACKGROUND}

Multidimensional epidemiological analyses, both cross-sectional and longitudinal, consistently indicate that the coexistence of mental disorders can be narrowed down to two spectra (dimensions): externalisation and internalisation (Kotov et al., 2017; Kendler, Prescott, Myers, \& Neale, 2003). The first of the above - the externalisation spectrum - contains such disorders as addiction to alcohol or other psychoactive substances, antisocial personality disorders or behaviour disorders. The second one - the internalisation spectrum - is linked with depression and other anxiety disorders (general anxiety, panic, phobias). Carragher et al. (2015) conducted an extensive meta-structure analysis of mental disorders. They highlighted the fundamental importance - for both theory and practice - of distinguishing hidden dimensions associated with the coexistence of disorders: the externalisation and internalisation spectrum. The externalisation dimension comprises: alcohol, drug addiction and anti-social personality disorders. The internalisation dimension consists of two subcategories. The first one is related to distress and fear, and includes depression, dystonia and generalised anxiety. The second subcategory is related to anxiety and includes social phobia, specific phobias, agoraphobia and panic disorders. Externalisation and internalisation are hidden transdiagnostic dimensions which are partly linked by a common aetiology, but also by similar treatment methods. The presented model is based on abundant empirical evidence (Krueger \& Markon, 2006). It establishes new ways of thinking that go beyond traditional classifications (ICD, DSM) and sets new research goals of an interdisciplinary nature.

Previous epidemiological studies indicate that women more often than men suffer from internalisation disorders. However, in recent decades there has been a significant increase in the occurrence of externalisation disorders in women. This trend is mainly reflected by a growth in crime as well as problems with alcohol and psychoactive substance abuse. In Poland, 3.3\% of working-age women experience problems with alcohol abuse. Every fifth person treated in addiction treatment centres is a woman (Kiejna et al., 2015; Dragan, 2016). Women who have been tried and convicted constitute $7-10 \%$ of the total convicted population. Between 1999 and 2008 it grew by 260\% (Machel, 2014; Szatkowska, 2012). In the US, $4.9 \%$ of women meet the criteria of alcohol addiction or abuse (Rehm et al., 2014). Between 1970 and 2014, there was a 14-fold growth of the number of convicted women in the US, from 8000 to 110000 (Lynch, DeHart, Belknap, \& Green, 2012). Nearly $82 \%$ of the convicted women in the US have experienced problems with abusing alcohol or other psychoactive substances during their lives. It is therefore an important and growing social problem in many developed countries, and the association between crime and the excessive use of psychoactive substances in women is strong.

In recent years, studies have been conducted on differences in aetiology of externalisation and internalisation spectrum disorders in men and women. However, the main focus was on their genetic background (Kendler et al., 2003). In men with externalisation disorders, a common genetic risk factor was associated with (decreasing order of its strength): antisocial personality disorders, alcohol dependence, drug dependence and behavioural disorders. In contrast, in women the order was different: drug/ medicine dependence, alcohol dependence, nicotine dependence, and, finally, antisocial personality disorders (Kendler \& Myers, 2014). Therefore, the risk factors leading to externalisation problems in women, such as addiction or crime, appear to be very different in nature from those in men (Mallicoat, 2014; Wong, Slotboom, \& Bijleveld, 2010). The study of Steadman et al. (2009) revealed that serious mental problems (depression, bipolar affective disorder, schizophrenia) affect respectively $32 \%$ of incarcerated women and $14.5 \%$ of incarcerated men. It is six times higher than in the general population of women in the US. This trend is further confirmed by the study of Lynch et al. (2014). Serious mental disorders occurred in $32 \%$ of the incarcerated women, $53 \%$ experienced a post-traumatic stress disorder during their lives, and as many as $82 \%$ abused or were addicted to alcohol or other substances during their lives. Green et al. (2005) demonstrated that $25 \%$ of the incarcerated women suffer from PTSD, and between 39 and $45 \%$ of them are affected by addiction to psychoactive substances. Hence, three main types of mental issues have been identified in incarcerated women - addictions, post-traumatic stress and serious mental disorders linked with depression, affective disorders or schizophrenia (Lynch et al., 2014; Swavola, Riley, \& Subramanian, 2016; Sosnowska, 2012). Also examined was the development trajectory of internalisation and externalisation problems covering different stages of an individual's life, from childhood to early adulthood (Korhonen, Luoma, Salmelin, Siirtola, \& Puura, 2018). No links have been found between the trajectory of internalisation problems and the quality of life, but such links appeared for externalisation issues. Internalisation problems in childhood were associated (but not at the clinical level) with a higher level of depression and avoidance personality, but with a lower level of antisocial problems. Puberty proved to be a very important period of changes. People with a growing level of internalisation problems in childhood and adolescence manifested more internalisation and externalisation problems in adulthood than people with a stable, either low or high level of internalisation problems. 
The co-occurrence of problems tended to considerably increase the risk of their intensification in adulthood. Attention was also drawn to the underlying causes of these problems in an attempt to address the question of which important factors determine the emergence of disorders from both groups. As demonstrated by the study of Thomas et al. (2014), negative emotionality linked with temperament is a major risk factor (among personality traits) for the development of PTSD. A pre-disorder personality with high negative emotionality and low positive emotionality predisposes a trauma-threatened person to develop internalisation disorders. On the other hand, a personality with high negative emotionality and low inhibition (disinhibition/constraint) is a predisposition to externalisation disorders. Apart from genetic or temperament inclinations, also emphasised were the environmental conditions, especially those related to experiencing adverse life events, and during childhood in particular (Kendler et al., 2003; Felitti, 2002).

For more than two decades, extensive population-based studies have been conducted to identify the risk of health problems in people who went through a number of unfavourable experiences in their families of origin during their childhood (adverse childhood experiences - ACEs). ACEs were defined as events that occurred before the age of 18 and which involved various types of violence in a family (physical, psychological), sexual abuse, emotional or physical negligence, witnessing domestic violence, excessive consumption of alcohol or psychoactive substances by a parent, mental disease of a parent, divorce or incarceration of a parent (Felitti, 2002; Larkin \& Records, 2007). Research on ACEs, initiated in the mid-1990s, was a breakthrough. It was the first time when relationships were explored between the comprehensive spectrum of trauma categories and their potential negative health effects at different stages of adult life. A systematic review and meta-analysis of 37 studies on ACEs in the general population was carried out by Hughes and her team (2017). It was found that the co-occurrence of different categories of ACEs is a serious risk factor for many dimensions of physical as well as mental health and underlies a broad range of mental and adjustment disorders. This risk can be transferred from generation to generation. The scope of health problems associated with ACEs has been called a 'hidden epidemic'.

Relatively few studies on ACEs examine the issue of externalisation disorders in women, particularly those with addiction history or a criminal record. Wong et al. (2010) carried out a review of studies on crime that took into account the issue of adverse childhood experiences, and Dragan (2016) did the same for studies on addictions. Messina and Grella (2006) conducted research among 500 female criminals addicted to psychoactive substances. It was revealed that as many as $31.8 \%$ of the incarcerated women had experienced at least four categories of ACEs during their childhood, as compared to $19.3 \%$ in non-incarcerated women. In the same study, the results of logistic regression analysis showed that the impact of adverse traumatic experiences on mental health is strong and increasing. Wong et al. (2010) demonstrated that adverse life experiences, poor bonds with mother, lack of her interest or support are the strongest factors related to women's crime. Still, are there any specific differences concerning the range and the character of adverse childhood experiences in women with generally defined externalisation and internalisation disorders? This is the main issue under consideration in the present study.

\section{AIM OF THE STUDY}

Previous studies conducted by Gąsior (2017, 2018) in a group of addicted and/or imprisoned women showed that this group is heterogeneous in terms of the occurrence of adverse childhood experiences. Still, their intensity is higher than in the general female population and is strongly associated with the functioning of parents and the symptoms of posttraumatic stress. The co-occurrence of addiction problems in the incarcerated women is linked with even higher intensity of ACEs. Both addiction and crime may be regarded as fundamental problems contributing to externalisation disorders. Associations of adverse childhood experiences with internalisation disorders and gender are commonly observed (Wysocka \& Ostafińska-Molik, 2015; Rosenfield \& Smith, 2010). However, it is not clear to what extent the externalisation and internalisation disorders in women are linked to adverse childhood experiences. Can their diversity be reflected in the severity of complex post-traumatic stress (complex PTSD)? While systematising insufficient knowledge in this scope and extending previous research projects, the following research question was formulated:

What are the differences in adverse childhood experiences, complex post-traumatic stress and attachment dimensions in women with different types - externalisation or internalisation - of adaptation disorders?

The answer to this question was sought by studying two clinical groups of women: (a) with externalisation disorders (addicted, addicted criminals), (b) with internalisation disorders (being treated for neurotic disorders, generalised anxiety, mixed anxiety-depressive disorders). The results were compared with the control group of women without health and adaptation problems. The selection of the examined individuals was aimed at maximising the variance of the variables relevant to the study, i.e. negative childhood experiences and symptoms of complex posttraumatic stress. 


\section{PARTICIPANTS AND PROCEDURE}

\section{PARTICIPANTS}

The studied clinical group comprised 159 women. The subgroup with externalisation problems (EXT; $n=80$ ) was distinguished to include addicted women, with 23 both addicted and imprisoned. Another subgroup contained women with internalisation issues (INT; $n=79$ ), treated for neurosis disorders (generalised anxiety, mixed anxiety-depressive disorders). The study also included a control group - women without adaptation issues $(N=129)$ - comprising students of part-time college courses and employees of different companies. The research focused mainly on comparing the clinical groups, as the previous studies consistently show significantly higher results in clinical trials among various clinical groups (women with addictions, anxiety disorders, etc.) compared to the groups from a general population. However, we also found it worth comparing the general results of clinical groups with the control group in order to verify this trend. The control group was not completely consistent with the clinical group in terms of demographic variables and therefore only general results of the research have been compared and possible conclusions were approached with caution.

The age bracket of the study participants was between 19 and 68 years, with the average of 37.8 $(S D=10.04)$ (34.9 years for the INT group, $S D=9.93$, and 39.8 years for the EXT group, $S D=10.62)$. With regard to education level, $32 \%$ had elementary and vocational education, $26.2 \%$ had secondary education and $41.9 \%$ had a higher education degree. More than $37 \%$ of the participants were single, $34.9 \%$ were married, $21.5 \%$ were divorced and $6.4 \%$ widowed. As regards the control group, the average age was 24.9 years (age bracket $18-52$ ), more than a half $(52 \%)$ had secondary education, and $47 \%$ had higher education. In the INT group, the predominating education levels were secondary and higher (bachelor's degree) (27.9\% and $67.1 \%$ respectively), whereas in the EXT group it was vocational (46.3\%), average (32\%) and higher $(21.3 \%)$. The marital status in the internalisation group was as follows: $48.1 \%$ were single, $41.8 \%$ married and $10.1 \%$ were widowed. In the externalisation group these numbers were respectively $30 \%$, $31.1 \%$ and $31.3 \%$.

\section{MEASURES}

Adverse Childhood Experiences - International Questionnaire (ACE-IQ). This measure was designed to study adverse childhood experiences. The WHO version, which was employed in this study (http://www. who.int/violence_injury_prevention/violence/activities/adverse_childhood_experiences/en/), is based on previous American versions created by Felitti and Anda (Felitti et al., 1998; Bellis et al., 2014). The questionnaire examines 13 categories of adverse childhood experiences: (1) physical abuse, (2) emotional abuse, (3) contact sexual abuse, (4) alcohol and/or drug abuser in the household, (5) incarcerated household member, (6) someone chronically depressed, mentally ill, institutionalized or suicidal, (7) household member treated violently, (8) one or no parents, parental separation or divorce, (9) emotional neglect, (10) physical neglect, (11) bullying, (12) community violence, (13) collective violence. The binary-version questionnaire (coding: 0,1 ) specifies whether a given category of adverse experiences has or has not occurred in the study participants. Thus, a participant may obtain between 0 and 13 points that describe the intensity of ACEs. The questionnaire was translated by Gąsior (2016) upon consent from the WHO.

Family of Origin Dysfunction Scale (FODS) by Gąsior (2012). The scale consists of 40 items contained in three parts: (1) family structure and functioning, (2) images of parents, (3) parental practices. The study focused on analysing the image of parents and their parental practices. The images of a mother and a father are described on a scale by pairs of opposing adjectives and regarded in the "positive-negative" categories. The way of living: calm - anxious; cheerful - depressed; impulsive - balanced. Thinking: clearminded - chaotic; irrational - organised and rational; prudent - imprudent. Behaviour: self-control - no self-control; able to achieve goals - unable to achieve goals; energy-deprived - energetic. Parental practices are linked with behaviour of parents (caregivers) in relations with their children and are defined by the measures of: love - indifference; care - negligence; control - lack of interest and supervision; good communication/understanding - no communication/understanding. The measure demonstrates good psychometric values, with a Cronbach's $\alpha$ value for FODS of .91 (Gąsior, 2014).

Trauma Symptom Inventory-2 (TSI-2) by Briere $(1995,2012)$. This is a newer version of the TSI inventory which examines the symptoms of post-traumatic stress and other psychological consequences of traumatic events. It was translated by Krzysztof Gąsior (as above), upon the consent of the author and the PCI publisher. The inventory includes symptoms of stress as well as the subjective or interpersonal problems related to its consequences. TSI- 2 includes 136 items in 2 control scales and 12 clinical scales. The reliability of the test was initially evaluated, with Cronbach's $\alpha$ of .97. Both versions of the test have good psychometric properties demonstrated in both American and Polish studies (Gąsior, 2014; Briere, 1995, 2012).

Adult Attachment Scale (AAS) by Collins and Read (1990). This method examines two categories (patterns) of insecure attachment: attachment anxiety and attachment avoidance. The scale is character- 
ised by good psychometric properties, including the Polish one (Łubiewska \& Van de Vijver, 2014).

Statistical analyses were performed by means of Statistica-12 and SPSS-10.

\section{RESULTS}

The first step of the analysis compared the groups of women with externalisation (EXT) and internalisation (INT) disorders in the scope of adverse childhood experiences. This stage employed Student's $t$-test and Cohen's $d$ effect size coefficient (Table 1).

To ensure the relevance of the identified differences between the means, the bootstrap test was used in line with generally accepted practice. It consists in examining whether the obtained bootstrap confidence interval of the difference between the means (at the assumed level of relevance) contains the value of zero. The absence of such a value in the confidence interval is the basis for rejecting the null hypothesis of no significant difference between the means (Wilcox, 2012).

The intensity of adverse childhood experiences (ACE) in both clinical groups is similar and is 6.46 for women with internalisation disorders (INT) and 6.05 in women with externalisation disorders (EXT). The profiles obtained in clinical groups differ in several scales. When compared to the EXT group, the women with INT disorders report more experiences of emotional violence, witnessing domestic violence and experiencing bullying at school. On the other hand, the EXT group was more exposed to collective violence and family disintegration. The strongest link, in terms of the effect size, was observed for the variable "witness of violence in domestic environment" (Cohen's $d=0.54$ ), the value of which can be referred to as moderate. With regard to relevance or its absence of differences between the means, the findings were confirmed by bootstrap analysis results (bootstrap 5000; $\mathrm{CI}=95 \%$ ).

What are the images of parents and parental practices in the compared groups? The analyses in this scope were performed by means of FODS and it revealed that the parental images only differ in the aspect of mother's emotionality (Table 2).

When compared to the INT group, the EXT women viewed their mothers as more emotionally labile, anxious and restless, often depressed and impulsive.

On the other hand, parental practices of the father indicate a significant difference between the two groups (Table 3).

As opposed to the EXT group, the INT group members reported more difficulties in establishing good understanding/communication (po_m; statistical trend); mothers had little regard for the child's opinion, and lack of understanding and communication was more frequent. The groups were differentiated by the factor of parental practices of the father. In

Table 1

Comparing groups of women with externalisation (EXT) and internalisation (INT) disorders (ACE-IQ)

\begin{tabular}{|c|c|c|c|c|c|c|c|}
\hline \multirow{2}{*}{$\begin{array}{l}\text { Group/ } \\
\text { type of experience }\end{array}$} & \multicolumn{2}{|c|}{ EXT } & \multicolumn{2}{|c|}{ INT } & \multirow[t]{2}{*}{$t$} & \multirow[t]{2}{*}{$p$} & \multirow{2}{*}{$\begin{array}{c}\text { Cohen's } \\
d\end{array}$} \\
\hline & M & $S D$ & M & $S D$ & & & \\
\hline 1. Physical abuse & 0.62 & 0.49 & 0.73 & 0.45 & -1.49 & .142 & ni \\
\hline 2. Emotional abuse* & 0.73 & 0.45 & 0.87 & 0.33 & -2.24 & $.021^{*}$ & 0.37 \\
\hline 3. Sexual abuse & 0.30 & 0.46 & 0.28 & 0.45 & 0.26 & .800 & ni \\
\hline 4. Alcohol, drug abuser & 0.64 & 0.49 & 0.73 & 0.44 & -1.32 & .194 & ni \\
\hline 5. Incarceration & 0.20 & 0.41 & 0.14 & 0.35 & 1.04 & .304 & ni \\
\hline 6. Depressed, mentally ill & 0.24 & 0.43 & 0.30 & 0.46 & -0.84 & .411 & ni \\
\hline 7. Domestic violence * & 0.77 & 0.42 & 0.95 & 0.22 & -3.25 & $.002^{*}$ & 0.54 \\
\hline 8. Parents separated ${ }^{*}$ & 0.59 & 0.49 & 0.43 & 0.50 & 2.05 & $.042^{*}$ & 0.33 \\
\hline 9. Emotional neglect & 0.12 & 0.33 & 0.06 & 0.24 & 1.24 & .223 & ni \\
\hline 10. Physical neglect & 0.54 & 0.50 & 0.63 & 0.49 & -1.16 & .254 & ni \\
\hline 11. Bullying* & 0.30 & 0.46 & 0.51 & 0.50 & -2.68 & $.008^{*}$ & 0.43 \\
\hline 12. Community violence & 0.77 & 0.42 & 0.72 & 0.45 & 0.69 & .494 & ni \\
\hline \multirow[t]{2}{*}{ 13. Collective violence * } & 0.23 & 0.42 & 0.09 & 0.29 & 2.40 & $.022^{*}$ & 0.39 \\
\hline & 6.05 & 3.22 & 6.46 & 2.42 & -0.87 & .390 & ni \\
\hline
\end{tabular}

Note. ${ }^{*} p \leq .05$; bootstrap $5000, \mathrm{Cl}=95 \%$; ni - low or very low result below 0.3 . 
Table 2

Comparing the image of a mother and a father in the group of women with internalisation (INT) and externalisation (EXT) disorders (FODS)

\begin{tabular}{|c|c|c|c|c|c|c|c|c|c|}
\hline & & & \multicolumn{2}{|c|}{ EXT } & \multicolumn{2}{|c|}{ INT } & \multirow[t]{2}{*}{$t$} & \multirow[t]{2}{*}{$p$} & \multirow{2}{*}{$\begin{array}{c}\text { Cohen's } \\
d\end{array}$} \\
\hline & & & $M$ & $S D$ & $M$ & $S D$ & & & \\
\hline \multirow{3}{*}{$\begin{array}{l}\text { OB_M } \\
\text { Mother }\end{array}$} & emotionality* & em_m* & -2.75 & 5.85 & -0.55 & 5.15 & -2.32 & $.019^{*}$ & 0.40 \\
\hline & thinking & my_m & -4.21 & 5.59 & -4.45 & 5.13 & 0.26 & .802 & ni \\
\hline & behaviour & za_m & -3.55 & 5.85 & -3.39 & 5.15 & -0.17 & .872 & ni \\
\hline \multirow{3}{*}{$\begin{array}{l}\text { OB_O } \\
\text { Father }\end{array}$} & emotionality & em_o & -2.14 & 4.94 & -1.53 & 5.13 & -0.69 & .489 & ni \\
\hline & thinking & my_o & -1.13 & 5.06 & -1.92 & 6.26 & 0.01 & .433 & ni \\
\hline & behaviour & za_o & -1.42 & 5.40 & -0.32 & 5.71 & -1.10 & .274 & ni \\
\hline
\end{tabular}

Note. ${ }^{*} p \leq .05$; bootstrap $5000, \mathrm{Cl}=95 \%$; ni - low or very low results below 0.3 .

Table 3

Comparing parental practices of a mother and a father in the group of women with internalisation (INT) and externalisation (EXT) disorders (FODS)

\begin{tabular}{|c|c|c|c|c|c|c|c|c|c|}
\hline & & & \multicolumn{2}{|c|}{ EXT } & \multicolumn{2}{|c|}{ INT } & \multirow[t]{2}{*}{$t$} & \multirow[t]{2}{*}{$p$} & \multirow{2}{*}{$\begin{array}{c}\text { Cohen's } \\
d\end{array}$} \\
\hline & & & $M$ & $S D$ & $M$ & $S D$ & & & \\
\hline \multirow{4}{*}{$\begin{array}{l}\text { PR_M } \\
\text { Mother's } \\
\text { practices }\end{array}$} & love & mi_m & 4.24 & 2.31 & 4.43 & 2.48 & -0.48 & .640 & ni \\
\hline & care & op_m & 4.06 & 2.32 & 4.25 & 1.82 & -0.56 & .571 & ni \\
\hline & control & ko_m & 4.16 & 2.09 & 4.62 & 2.13 & -1.31 & .189 & ni \\
\hline & $\begin{array}{l}\text { communication/ } \\
\text { understanding }\end{array}$ & po_m\# & 5.26 & 2.53 & 5.91 & 2.22 & -1.67 & $.090 \#$ & 0.29 \\
\hline \multirow{4}{*}{$\begin{array}{l}\text { PR_O } \\
\text { Father's } \\
\text { practices }\end{array}$} & love* & mi_o* & 4.21 & 2.48 & 5.34 & 2.49 & -2.72 & $.007^{*}$ & 0.45 \\
\hline & care $^{*}$ & op_o* & 4.60 & 2.43 & 5.65 & 2.13 & -2.76 & $.007^{*}$ & 0.46 \\
\hline & control $^{*}$ & ko_o* & 4.76 & 2.28 & 5.73 & 1.98 & -2.72 & $.007^{*}$ & 0.46 \\
\hline & $\begin{array}{l}\text { communication/ } \\
\text { understanding* }\end{array}$ & po_o* & 5.33 & 2.56 & 6.50 & 1.98 & -3.00 & $.003^{*}$ & 0.52 \\
\hline
\end{tabular}

Note. ${ }^{*} p \leq .05$; \# statistical trend; bootstrap $5000, \mathrm{Cl}=95 \%$; ni - low or very low results below 0.3 .

the INT group, the father showed fewer signs of love and acceptance, neglected the child more often, demonstrated little interest in the child's affairs and it was more difficult to communicate with him. The measure of the relationship strength (Cohen's $d$ ) for parental practices was found to be around moderate values.

The following step of the analyses compared the groups in terms of intensity and range of the complex post-traumatic stress as well as the attachment dimensions (TSI-2). A detailed examination indicates that both groups of women differ significantly in several important symptoms of the complex posttraumatic stress (Table 4). The women with EXT disorders demonstrate a higher intensity of defensive avoidance (DA), dysfunctional sexual behaviour (SXD_DSB), suicidal tendencies and behaviour (SUI, SUI_B) and tension reduction behaviour even though the general intensity of the post-traumatic stress is similar in both groups.

Let us consider the dimensions of attachment in the compared groups. The TSI- 2 test revealed no differences in this scope. However, the AAS indicates that such discrepancies do exist (Table 5). Women in the EXT group demonstrate stronger tendencies of refraining from intimacy, withdrawing from interpersonal relations and avoiding potential support from others (Av). The strongest link, in terms of the magnitude of the effect (moderate values), occurred in the case of defensive avoidance (DA) and suicidal behaviour (SUI_B). It is worth noting the differences between the main test factors: self-disorders (SELF), post-traumatic stress (TRAUMA), externalisation (EXT) and somatisation (SOMA). As opposed to the women with externalisation disorders, it may be assumed (based on the 
Table 4

Comparing the intensity of the complex post-traumatic stress in women with internalisation (INT) and externalisation (EXT) disorder (TSI-2)

\begin{tabular}{|c|c|c|c|c|c|c|c|}
\hline \multirow[t]{2}{*}{ Scale } & \multicolumn{2}{|c|}{ EXT } & \multicolumn{2}{|c|}{ INT } & \multirow[t]{2}{*}{$t$} & \multirow[t]{2}{*}{$p$} & \multirow{2}{*}{$\begin{array}{c}\text { Cohen's } \\
d\end{array}$} \\
\hline & $M$ & $S D$ & $M$ & $S D$ & & & \\
\hline ATR $^{*}$ & 6.43 & 4.85 & 4.41 & 4.20 & 2.75 & $.011^{*}$ & 0.45 \\
\hline$R L$ & 0.66 & 0.99 & 0.76 & 0.98 & -0.61 & .543 & ni \\
\hline $\mathrm{AA}$ & 16.45 & 6.17 & 16.20 & 6.24 & 0.24 & .812 & ni \\
\hline AA_A & 8.35 & 3.31 & 8.58 & 3.39 & -0.43 & .667 & ni \\
\hline AA_H & 8.09 & 3.31 & 7.62 & 3.24 & 0.90 & .374 & ni \\
\hline D & 17.64 & 7.39 & 16.06 & 7.20 & 1.33 & .181 & ni \\
\hline $\mathrm{Al}$ & 13.58 & 6.49 & 13.66 & 6.52 & -0.07 & .944 & ni \\
\hline IE & 13.96 & 6.58 & 12.34 & 7.14 & 1.46 & .150 & ni \\
\hline $\mathrm{DA}^{*}$ & 15.95 & 6.18 & 13.29 & 6.78 & 2.53 & $.011^{*}$ & 0.41 \\
\hline DIS\# & 9.41 & 6.48 & 7.75 & 5.81 & 1.67 & $.089 \#$ & 0.27 \\
\hline SOM\# & 12.96 & 6.51 & 11.16 & 6.58 & 1.70 & $.088 \#$ & 0.28 \\
\hline SOM_P* & 6.61 & 2.84 & 5.58 & 3.10 & 2.13 & $.039^{*}$ & 0.34 \\
\hline SOM_G & 6.35 & 4.07 & 5.58 & 4.13 & 1.16 & .251 & ni \\
\hline SXD & 5.65 & 5.15 & 4.96 & 5.07 & 0.83 & .411 & ni \\
\hline SXD_SC & 3.51 & 3.65 & 3.62 & 3.67 & -0.18 & .858 & ni \\
\hline SXD_DSB* & 2.14 & 2.46 & 1.34 & 1.95 & 2.22 & $.028^{*}$ & 0.36 \\
\hline SUI* & 5.72 & 7.60 & 3.34 & 4.86 & 2.29 & $.026^{*}$ & 0.38 \\
\hline SUI_I & 3.54 & 4.41 & 2.81 & 3.97 & 1.08 & .280 & ni \\
\hline SUI_B* & 2.18 & 3.50 & 0.53 & 1.24 & 3.82 & $.001^{*}$ & 0.63 \\
\hline IA & 14.19 & 6.27 & 13.92 & 6.75 & 0.25 & .802 & ni \\
\hline IA_RA & 7.05 & 3.20 & 6.62 & 3.66 & 0.78 & .443 & ni \\
\hline IA_RS & 7.14 & 3.66 & 7.30 & 3.91 & -0.28 & .778 & ni \\
\hline ISR & 12.28 & 6.30 & 11.91 & 7.02 & 0.35 & .732 & ni \\
\hline ISR_RSA & 6.14 & 3.52 & 5.99 & 4.18 & 0.24 & .810 & ni \\
\hline ISR_OD & 6.15 & 3.57 & 5.92 & 3.66 & 0.38 & .703 & ni \\
\hline TRB* & 9.86 & 6.48 & 7.78 & 5.89 & 2.08 & $.041^{*}$ & 0.34 \\
\hline SELF & 44.11 & 18.16 & 41.90 & 19.02 & 0.73 & .453 & ni \\
\hline TRAUMA\# & 55.76 & 22.25 & 49.58 & 21.76 & 1.74 & $.078 \#$ & 0.28 \\
\hline EXT & 34.81 & 21.60 & 29.75 & 18.11 & 1.58 & .121 & ni \\
\hline SOMA\# & 12.96 & 6.51 & 11.16 & 6.58 & 1.70 & $.088 \#$ & 0.28 \\
\hline
\end{tabular}

Note. RL - response level, ATR - atypical response, AA - anxious arousal, AA-A - anxiety, AA-H - hyperarousal, D - depression, $\mathrm{AI}$ - anger/irritability, IE - intrusive experiences, DA - defensive avoidance, DIS - dissociation, SOM - somatic preoccupations, SOM-P - pain, SOM-G - general, SXD - sexual disturbance, SXD-SC - sexual concerns, SXD-DSB - dysfunctional sexual behaviour, SUI - suicidality, SUI-I - suicidal ideation, SUI-B - suicidal behaviour, IA - insecure attachment, IA-RA - relational avoidance, IA-RS - rejection sensitivity, ISR - impaired self-reference, ISR-RSA - reduced self-awareness, ISR-OD - other-directedness, TRB - tension reduction behaviour, SELF - self-disturbance, TRAUMA - post-traumatic stress, EXT - externalisation, SOMA - somatisation. ${ }^{*} p \leq .05$; \# statistical trend; bootstrap $5000, \mathrm{Cl}=95 \%$; ni - low or very low results below 0.3 . 
Table 5

Comparing the attachment dimensions in the externalisation (EXT) and the internalisation (INT) group - AAS

\begin{tabular}{|c|c|c|c|c|c|c|c|c|}
\hline \multirow[t]{2}{*}{ Attachment categories } & & \multicolumn{2}{|c|}{ EXT } & \multicolumn{2}{|c|}{ INT } & \multirow[t]{2}{*}{$t$} & \multirow[t]{2}{*}{$p$} & \multirow[t]{2}{*}{ Cohen's $d$} \\
\hline & & $M$ & $S D$ & $M$ & $S D$ & & & \\
\hline Avoidance attachment & $A v$ & 26.22 & 6.57 & 24.14 & 6.36 & 1.99 & .048 & 0.32 \\
\hline Anxiety attachment & $A x$ & 36.19 & 10.46 & 34.68 & 10.73 & 0.88 & .377 & ni \\
\hline General score & AASsum & 58.82 & 14.69 & 28.57 & 7.98 & 1.48 & .140 & ni \\
\hline
\end{tabular}

Note. bootstrap $5000 \mathrm{Cl}=95 \%$; ni - low or very low result below 0.3

Table 6

Comparing the general test results in the internalisation group INT (1), the externalisation group EXT (2) and the control group $K(3)$

\begin{tabular}{lrrrrrrrrr}
\hline \multirow{2}{*}{ Scale } & \multicolumn{3}{c}{ INT (1) } & \multicolumn{2}{c}{ EXT (2) } & \multicolumn{2}{c}{ K (3) } & \multirow{2}{*}{$F$} & \multicolumn{2}{c}{$\begin{array}{c}\text { Post-hoc } \\
\text { test }\end{array}$} \\
\cline { 2 - 8 } & \multicolumn{1}{c}{$M$} & \multicolumn{1}{c}{$S D$} & $M$ & $S D$ & $M$ & \multicolumn{1}{c}{$S D$} & & \\
\hline ACE-IQ & 6.46 & 2.42 & 6.05 & 3.22 & 2.84 & 2.13 & $57.94^{*}$ & $1-3 ; 2-3$ \\
FODS (parental image) & -13.15 & 22.69 & -16.47 & 24.07 & -43.52 & 19.12 & $49.28^{*}$ & $1-3 ; 2-3$ \\
FODS (parental practices) & 41.61 & 10.56 & 36.53 & 14.45 & 27.97 & 9.58 & $33.00^{*}$ & $1-3 ; 1-2 ; 2-3$ \\
TSI-2 & 132.39 & 58.56 & 142.26 & 64.84 & 75.96 & 48.03 & $43.80^{*}$ & $1-3 ; 2-3$ \\
AAS & 58.82 & 14.69 & 62.02 & 14.88 & 50.53 & 14.40 & $18.01^{*}$ & $1-3 ; 2-3$ \\
\hline
\end{tabular}

Note. $1-2 ; 1-3 ; 2-3$ - significant differences $(p \leq .05)$ between the groups; ${ }^{*} p \leq .001$.

statistical trends) that women in the INT group present higher intensity of symptoms of post-traumatic stress and higher focus on somatic health.

At the end of the analysis, the general results of ACE-IQ, FODS (parental images and parental practices), TSI-2 and AAS tests of clinical and control groups were compared (Table 6). Analysis of variance (ANOVA) was also applied.

The clinical groups INT and EXT differ significantly from the control group K, obtaining higher scores in all the tests. This proves the higher intensity of the adverse childhood experiences (ACE-IQ), negative image of parents and their parental practices (FODS), symptoms of the complex post-traumatic stress and insecure attachment categories in the clinical groups.

\section{DISCUSSION}

The analyses showed a similar level of intensity of adverse childhood experiences (ACE) in the women with externalisation and internalisation disorders. In both groups the average ACE intensity was observed at the level of 6th category. Moreover, this level differed significantly and was twice as high compared to the control group, where the average level of ACE was below the 3rd category of ACE. This is consistent with the previous studies which indicate more frequent occur- rence of childhood traumatic experiences in persons with mental and adaptation problems when compared to the general population (Rossegger et al., 2009; Felitti, 2002; Reavis, Looman, Franco, \& Rojas, 2013). However, studies have shown a certain specificity of childhood experiences in women with externalisation and internalisation disorders. Namely, women from the INT group more often experienced emotional violence (name calling, offending, humiliating, threatening) from the parent and more often witnessed domestic violence (physical attacks or insulting and humiliating a household member). Characteristically, women from this group were also more often victims of bullying and persecution at school. The forms of violence described above are of relational nature and are mainly linked to the family and school environment. On the other hand, the women from the EXT group more often experienced family disintegration and collective violence in a non-family environment (e.g. beatings, gang persecution). These forms of negative experiences are mainly of a family nature, and, what is more, some of them are connected with the non-family environment. Studies on externalisation disorders in girls and women clearly indicate the importance of not only the family home, but also the non-family environment in developing adaptation problems (Messer, Maughan, Quinton, \& Taylor, 2004). The present study revealed that relational problems in the family in both groups 
play an important role in the formation of both spectra of disorders, but it is the non-family environment which seems to have a significant influence on the trajectory of externalisation disorders. However, a situation of family disintegration and the long-lasting conflict associated with it may to a large extent "push" the child into a risky environment (Rosenbaum, 1989). By intensifying avoidance personality traits or tendencies to isolate oneself, internalisation of problems may "close" the children to the environment, thus, paradoxically, protecting them from externalisation of the problems. Korhonen et al. (2018) pointed to this role of internalisation when they studied the development trajectory of internalisation and externalisation issues.

The differences in the retrospective image of parents' functioning and their parental practices in clinical groups are interesting. In the EXT group, women reported more relationship problems with their mothers, who they perceived as emotionally unstable, restless and anxious, explosive and depressed. In terms of parental practices, INT women compared to EXT women pointed to the occurrence of more dysfunctional practices in the father, in terms of acceptance, care, control and understanding. This is indicated by a much worse relationship of the INT group with both parents, but the relationship with the mother seems to be more difficult in the EXT group. This is partly consistent with Wong's meta-analyses (2010), which showed that women criminals have more relationship problems with their mothers than men. Nevertheless, it is worth noting that a greater intensity of general relational problems in the family of origin and the child's involvement in them are more frequent among women with internalisation problems. In contrast, situational traumas such as family disintegration and collective violence increase the risk of girls becoming involved in a risky environment, which may be linked to the onset or consolidation of externalisation disorders. On the other hand, it seems that the child's involvement in relational problems in the family, such as emotional violence or witnessing violence against an adult household member (most often the mother), or the experience of bullying in school, may increase the tendency to close oneself in these experiences and one's own world. Paradoxically, it may protect the child from becoming involved in the environment. If the environment is dangerous, such "blockade" may protect the child against externalisation of problems. If, however, the environment is protective, then such a situation limits the possibilities of helping the individual and locks them in the world of internalisation issues.

General severity of complex post-traumatic stress in both clinical groups is similar and higher than in the control group. Still, differences do occur between clinical groups. Women in the EXT group demonstrate a higher level of dysfunctional sexual disorders as well as auto-aggressive suicidal behav- iour and tension-reducing behaviour. These symptoms are strongly associated with externalisation disorders, with discharging tension outside, but also with directing it against oneself. In addition, EXT women are more likely to use defensive avoidance as a way of dealing with traumas. Moreover, they tend to evade intimacy and to withdraw from close ties as they build intimate relations. The study by Gąsior (2017) in the group of only incarcerated and addicted women also revealed the dominance of insecure types of attachment. Lynch et al. (2012) and Dragan (2016) have proved that incarcerated or addicted women were more often than men the victims of chronic interpersonal violence, not only during childhood but also later, in adult relationships. Thus, avoiding closeness or experiencing difficulties with establishing intimate relationships may be a defence mechanism, not just against intrusions of the past but also against current problems in relationships.

The limitations of the research result mainly from the small size of the examined group, which narrows the force of the conclusions. Moreover, the control group was not very consistent with the clinical groups in terms of age and education. Therefore, it was decided not to conduct detailed comparative analyses between the control group and the clinical group and only the general results were compared. For future studies, it is advisable to select a control group that is more consistent with the clinical group. Education and marital status also differed to some extent in the clinical groups (EXT and INT), so more coherent groups should be selected in the future or these demographic variables should be supervised more strictly. Future research should also highlight the role of temperamental variables in the formation of externalisation and internalisation disorders. Another significant limitation of the research was the lack of control over the type of crime, personality disorders in incarcerated women, and the depth of addiction. These variables, as mediators, may influence the strength of relationships. On the other hand, is precisely this and not the other choice of types of maladjustment that makes it possible to provide a broader view of the spectra of externalisation or internalisation problems, defined not only in terms of mental health, but also in terms of adaptation.

\section{CONCLUSIONS}

The aim of the study was to seek links between adverse childhood experiences and complex posttraumatic stress and attachment in view of the externalisation and internalisation disorders in women. Thanks to the research, it was possible to identify common and specific risk factors as well as the severity of symptoms of complex post-traumatic stress in both spectrums of disorders (Table 7). 
Table 7

Specific and common risk factors, as well as the symptoms of the complex post-traumatic stress and attachment in women with externalisation and internalisation disorders

\begin{tabular}{|c|c|c|c|}
\hline Risk factors & Common & $\begin{array}{l}\text { Specific to internalisation } \\
\text { disorders (anxiety disorders, } \\
\text { mixed anxiety-depressive } \\
\text { disorders) }\end{array}$ & $\begin{array}{l}\text { Specific to externalisation } \\
\text { disorders (addictions, } \\
\text { crime) }\end{array}$ \\
\hline $\begin{array}{l}\text { Adverse } \\
\text { childhood } \\
\text { experiences } \\
(A C E)\end{array}$ & $\begin{array}{l}\text { General level of ACE } \\
\text { similar in both groups; } \\
\text { high - on average } \\
\text { category } 6 \text { and higher }\end{array}$ & $\begin{array}{l}\text { Family: emotional violence, } \\
\text { witnessing domestic violence } \\
\text { Non-family: bullying at school }\end{array}$ & $\begin{array}{l}\text { Family: family disintegration } \\
\text { Non-family: exposed to col- } \\
\text { lective violence }\end{array}$ \\
\hline $\begin{array}{l}\text { Parents' } \\
\text { functioning }\end{array}$ & $\begin{array}{l}\text { General image of par- } \\
\text { ents' functioning and } \\
\text { their dysfunctional } \\
\text { parental practices }\end{array}$ & $\begin{array}{l}\text { Father: with highly dysfunc- } \\
\text { tional parental practices in } \\
\text { scope of love and child's } \\
\text { acceptance, care, control, } \\
\text { showing interest and commu- } \\
\text { nication }\end{array}$ & $\begin{array}{l}\text { Mother: emotionally labile, } \\
\text { restless, anxious, impul- } \\
\text { sive, depressed; in scope of } \\
\text { parental practices: difficul- } \\
\text { ties in communicating and } \\
\text { contact with a child }\end{array}$ \\
\hline $\begin{array}{l}\text { Complex } \\
\text { post-traumatic } \\
\text { stress and } \\
\text { current } \\
\text { attachment } \\
\text { patterns }\end{array}$ & $\begin{array}{l}\text { High or elevated in- } \\
\text { tensity of the complex } \\
\text { post-traumatic stress } \\
\text { and insecure attach- } \\
\text { ment patterns }\end{array}$ & & $\begin{array}{l}\text { Higher intensity of defen- } \\
\text { sive avoidance, dysfunc- } \\
\text { tional sexual behaviour, } \\
\text { suicidal tendencies and } \\
\text { behaviour - tendencies for } \\
\text { avoidance attachment }\end{array}$ \\
\hline
\end{tabular}

The results obtained and the conclusions drawn from the research indicate that it is necessary to include a detailed diagnosis of adverse childhood experiences and traumas in the therapy and social rehabilitation of women with internalisation and externalisation disorders. Only such extended diagnosis will allow for constructing more individualised psychotherapeutic and assistance programmes. The present study confirms that it is necessary to look more closely at the coexisting disorders in the form of the internalisation and externalisation spectrums. In fact, although the development trajectories of these disorders may vary, they are still characterised not only by a common and specific genetic background, but probably also by the environmental one.

\section{RESEARCH ETHICS}

The authors declare that the research conforms to the provisions of the Declaration of Helsinki.

\section{References}

Bellis, M., Hughes, K., Leckenby, N., Jones, L., Baban, A., Kachaeva, M., Povilatis, R., Pudule, I., Qirjako, G., Ulukol, B., Raleva, M., \& Terzic, N. (2014). Adverse childhood experiences and associations with health-harming behaviors in young adults: Surveys in eight eastern European countries. Bulletin of the World Health Organization, 92, 641-655B. https://doi.org/10.2471/BLT.13.129247

Briere, J. (1995). Trauma Symptom Inventory. Lutz, FL: Psychological Assessment Resources.

Briere, J. (2012). Trauma Symptom Inventory-2. Lutz, FL: Psychological Assessment Resources.

Carragher, N., Krueger, R. F., Eaton, N. R., \& Slade, T. (2015). Disorders without borders: Current and future directions in the meta-structure of mental disorders. Social Psychiatry and Psychiatric Epidemiology, 50, 339-350. https://doi.org/10.1007/ s00127-014-1004-z

Collins, N. L., \& Read, S. J. (1990). Adult attachment, working models, and relationship quality in dating couples. Journal of Personality and Social Psychology, 54, 644-663. https://doi.org/10.1037/00223514.58.4.644

Dragan, M. (2016). Problemowe picie alkoholu przez mtode kobiety. Rola niekorzystnych doświadczeń i samoregulacji emocji [Problematic drinking by young women. The role of adverse experiences and self-regulation of emotions]. Warszawa: Wydawnictwo Naukowe Scholar.

Felitti, V. J. (2002). The relation between adverse childhood experiences and adult health: Turning gold into lead. The Permanente Journal, 6, 44-47.

Felitti, V. J., Anda, R. F., Nordenberg, D., Williamson, D. F., Spitz, A. M., Edwards, V., Koss, M. P., \& Marks, J. S. (1998). Relationship of childhood 
abuse and household dysfunction to many of the leading causes of death in adults. The adverse childhood experiences (ACE) study. American Journal of Preventive Medicine, 14, 245-258. https://doi. org/10.1016/S0749-3797(98)00017-8

Gąsior, K. (2012). Funkcjonowanie noo-psychospoteczne i problemy psychiczne dorostych dzieci alkoholików [Psychosocial functioning and psychopatological problems of adult childern of alcoholics]. Warszawa: Difin.

Gąsior, K. (2014). Diversifying childhood experiences of adult children of alcoholics. Alcoholism and Drug Addiction, 27, 289-304. https://doi.org/10.1016/ S0867-4361(14)70021-5

Gąsior, K. (2016). Międzynarodowy Kwestionariusz Negatywnych Doświadczeń Dzieciństwa - polskie tłumaczenie i adaptacja [Adverse Childhood Experiences - International Questionnaire - Polish translation and adaptation]. Unpublished manuscript.

Gąsior, K. (2017). Post-traumatic stress and attachment in incarcerated women - the role of risk and protective factors. Polskie Forum Psychologiczne, 22, 420-439. https://doi.org/10.14656/PFP20170305

Gąsior, K. (2018). The links between posttraumatic stress, attachment patterns and quality of life in incarcerated and addicted women. The role of resilience. Psychiatria Polska, 52, 1113-1125. https:// doi.org/10.12740/PP/OnlineFirst/76823

Green, B. L., Miranda, J., Daroowalla, A., \& Siddique, J. (2005). Trauma exposure, mental health functioning and program needs of women in jail. Crime and Delinquency, 51, 133-151. https://doi. org/10.1177/0011128704267477

Hughes, K., Bellis, M. A., Hardcastle, K. A., Sethi, D., Butchart, A., Mikton, C., Jones, L., \& Dunne, M. P. (2017). The effect of multiple adverse childhood experiences on health: a systematic review and meta-analysis. The Lancet Public Health, 2, e356-e366. https://doi.org/10.1016/S2468-2667(17)30118-4

Kendler, K. S., \& Myers, J. (2014). The boundaries of the internalizing and externalizing genetic spectra in men and women. Psychological Medicine, 44, 647655. https://doi.org/10.1017/S0033291713000585

Kendler, K. S., Prescott, C. A., Myers, J., \& Neale, M. C. (2003). The structure of genetic and environmental risk factors for common psychiatric and substance use disorders in men and women. Archives of General Psychiatry, 60, 929-937. https://doi. org/10.1001/archpsyc.60.9.929

Kiejna, A., Piotrowski, P., Adamowski, T., Moskalewicz, J., Wciórka, J., Stokwiszewski, J., Rabczenko, D., \& Kessler, R. C. (2015). The prevalence of common mental disorders in the population of adult Poles by sex and age structure - an EZOP Poland study. Psychiatria Polska, 49,15-27. https:// doi.org/10.12740/PP/30811

Korhonen, M., Luoma, I., Salmelin, R., Siirtola, A., \& Puura, P. (2018). The trajectories of internalizing and externalizing problems from early childhood to adolescence and young adult outcome. Journal of Child and Adolescent Psychiatry, 2, 7-12.

Kotov, R., Krueger, R. F., Watson, D., Achenbach, T. M., Althoff, R. R., Bagby, ... Zimmerman, M. (2017). The Hierarchical Taxonomy of Psychopathology (HiTOP): a dimensional alternative to traditional nosologies. Journal of Abnormal Psychology, 126, 454-477. https://doi.org/10.1037/abn0000258

Krueger, R. F., \& Markon, K. E. (2006). Understanding psychopathology: Melding behavior genetics, personality, and quantitative psychology to develop an empirically based model. Current Directions in Psychological Science, 15, 113-117. https://doi. org/10.1111/j.0963-7214.2006.00418.x

Larkin, H., \& Records, J. (2007). Adverse childhood experiences: Overview, response strategies, and integral theory. Journal of Integral Theory and Practice, 2, 1-25.

Lynch, S. M., DeHart, D. D., Belknap, J. E, \& Green, B. L. (2012). Women's pathways to jail: The roles \& intersections of serious mental illness \& trauma. Bureau of Justice Assistance. Retrieved from https://www.bja. gov/Publications/Women_Pathways_to_Jail.pdf

Lynch, S. M., DeHart, D. D., Belknap, J. E, Green, B. L., Dass-Brailsford, P., Johnson, K. A., \& Whalley, E. (2014). A multisite study of the prevalence of serious mental illness, PTSD, and substance use disorders of women in jail. Psychiatric Services, 65, 670-674 https://doi.org/10.1176/appi.ps.201300172

Łubiewska, K., \& Van de Vijver, A. J. (2014). Attachment types or dimensions: Evidences form the Adult Attachment Scale across three generations. Unpublished manuscript.

Machel, H. (2014). Przestępczość kobiet i wobec kobiet - spojrzenie kryminologiczno-penitencjarne [Female criminality and crime against women a criminological-penitentiary view]. Resocjalizacja Polska, 8, 13-25.

Mallicoat, S. L. (2014). Women and crime. Thousand Oaks, CA: Sage Publications.

Messer, J., Maughan, B., Quinton, D., \& Taylor, A. (2004). Precursors and correlates of criminal behaviour in women. Criminal Behaviour and Mental Health, 14, 82-107. https://doi.org/10.1002/cbm.575 Messina, N., \& Grella, C. (2006). Childhood trauma and women's health outcomes in California prison population. American Journal of Public Health, 96, 18421848. https://doi.org/10.2105/AJPH.2005.082016

Reavis, J. A., Looman, J., Franco, K. A., \& Rojas, B. (2013). Adverse childhood experiences and adult criminality: How long must we live before we possess our own lives? The Permanente Journal, 17, 44-48. https://doi.org/10.7812/TPP/12-072

Rehm, J., Dawson, D., Frick, U., Gmel, G., Roerecke, M., Shield, K. D., \& Grant, B. (2014). Burden of disease associated with alcohol use disorders in the United States. Alcoholism: Clinical and Experimen- 
tal Research, 38, 1068-1077. https://doi.org/10.1111/ acer. 12331

Rosenbaum, J. (1989). Family dysfunction and female delinquency. Crime \& Delinquency, 31, 31-44. https://doi.org/10.1177/0011128789035001003

Rosenfield, S., \& Smith, D. (2010). Gender and mental health: Do men and women have different amounts or types of problems? In T. L. Scheid \& T. N. Brown (Eds.), A handbook for the study of mental health: Social contexts, theories, and systems (pp. 256-267). New York: Cambridge University Press.

Rossegger, A., Wetli, N., Urbaniok, F., Elbert, T., Cortoni, F., \& Endrass, J. (2009). Women convicted for violent offenses: Adverse childhood experiences, low level of education and poor mental health. BMC Psychiatry, 9, article 81. https://doi.org/10.1186/1471244X-9-81

Sosnowska, E. (2012). Sytuacja życiowa kobiet przestępczyń - wybrane aspekty wiktymizacyjne [Life situation of female criminals - selected victimization aspects]. Prace Naukowe Akademii im. Jana Długosza w Częstochowie, 21, 263-273.

Steadman, H. J., Osher, F. C., Robbins, P. C., Case, B., \& Samuels, S. (2009). Prevalence of serious mental illness among jail inmates. Psychiatric Services, 60, 761-765. https://doi.org/10.1176/ps.2009.60.6.761

Swavola, E., Riley, K., \& Subramanian, R. (2016). Overlooked: Women and jails in an era of reform. New York: Vera Institute of Justice.

Szatkowska, A. (2012). Przestępczość kobiet w Polsce w XIX, XX i XXI wieku [Women's crime in Poland in the 19th, 20th and 21st centuries]. Przegląd Więziennictwa Polskiego, 74/75, 213-230.

Thomas, K. M., Hopwood, C. J., Donnellan, M. B., Wright, A. G. C., Sanislow, C. A., McDevitt-Murphy, M. E., Ansell, E. B., Grilo, C. M., McGlashan, T. H., Shea, M. T., Markowitz, J. C., Skodol, A. E., Zanarini, M. C., \& Morey, L. C. (2014). Personality heterogeneity in PTSD: Distinc temperament and interpersonal typologies. Psychological Assessment, 26, 23-34. https://doi.org/10.1037/a0034318

Wilcox, R. (2012). Modern statistics for the social and behavioral sciences. A practical introduction. Boca Raton, FL: CRC Press.

Wong, T. M., Slotboom, A. M., \& Bijleveld, C. C. (2010). Risk factors for delinquency in adolescent and young adult females: a European review. European Journal of Criminology, 7, 266-284. https:// doi.org/10.1177/1477370810363374

Wysocka, E., \& Ostafińska-Molik, B. (2015). Rodzina w percepcji i doświadczeniach młodzieży prawidłowo i wadliwie przystosowanej - analiza porównawcza [Family in the perception and experience of suitably and unsuitably adapted young people - comparative analysis]. Pedagogika Spoteczna, 2, 131-154. 